\section{Respiratory monitoring of the infant in anaesthesia and intensive care}

Katsuyuki Miyasaka MD
Children during general anaesthesia and critical care often require intensive respiratory support. However, routine respiratory evaluation often does not include anything beyond blood gas analysis probably because it is thought that respiratory function tests are very difficult to perform in paediatric patients.

The small physical size of paediatric patients makes for a small signal-to-noise ratio of all the respiratory variables measured. Continuity, fast response, and less invasiveness are important characteristics of paediatric monitoring and frequently outweigh the importance of accuracy and specificity. Accuracy and specificity can be reasonably well compensated for by the combined use of many indirect but continuous monitoring variables. Situations are frequently encountered in paediatric clinical practice where having some information of lesser quality is more helpful than having no information.

Recent progress in respiratory physiology and computer technology has made it possible to apply, even at the bedside, many sophisticated pulmonary function tests which once were confined to the laboratory.

\section{Observation of chest wall movement}

Because of the difficulties in obtaining specific and objective data from paediatric patients, acquisition of physical information remains of paramount importance. In addition to the usual signs of respiratory distress, such as increased respiratory rate, chest wall retraction and use of accessory respiratory muscles, the careful evaluation of abdomen and rib cage coordination is important. During spontaneous inspiration the chest wall and abdomen should move outward in a synchronous fashion. Paradoxical respiration or discoordinated breathing, which means that the abdomen and chest wall move in opposite directions, is observed when a patient is suffering from phrenic nerve paralysis or respiratory muscle fatigue. ${ }^{1}$

\section{Precordial stethoscope}

The importance of continuous monitoring with a precordial stethoscope cannot be stressed too much, especially during anaesthesia. A stethoscope is probably the single most useful anaesthesia monitor. It can monitor cardiac and respiratory function at the same time, continuously and noninvasively. It is very economical, no electricity is required and it keeps the anaesthetist close to the patient at all times. A recent survey of ours showed that, in all 14 children's hospitals in Japan, the continuous use of a precordial stethoscope in all cases along with other basic monitoring such as the body temperature thermister and blood pressure sphygmometer has been mandated.

\section{Mini-fibrebronchoscope}

The majority of patients in paediatric anaesthesia and critical care have tracheal tubes (TT) or tracheostomy cannulae so that the maintenance of airway patency is of extreme importance. A small bore fibrebronchoscope is a useful tool to monitor airway patency at the bedside. The smallest fibrebronchoscope with adjustable angulation has an outer diameter of $2.4 \mathrm{~mm}$ and passes through a neonatal $2.5 \mathrm{~mm} / \mathrm{TT}$ quite easily. Confirmation of TT patency and differential diagnosis of airway obstruction can be done very easily and promptly and avoids many unnecessary reintubations.

\section{Gas exchange variables}

Arterial lines and arterial blood gas analyses

Although less invasive forms of monitoring are preferable, and although important advances have been made such as noninvasive blood pressure measurement devices, pulse oximeters and capnometers, the use of the arterial line cannot be eliminated from paediatric critical care. Experience in the use of arterial lines in paediatric patients over the past two decades has taught us many important lessons. It is important to select a peripheral rather than a central artery and to cannulate percutaneously rather than surgically. ${ }^{2}$ Non tapered and smaller size (22G or $24 \mathrm{G}$ ) catheters should be used. When the radial artery is

Department of Anesthesia and ICU National Children's Hospital, Setagaya, Tokyo Japan 154 
selected the left side is preferred for anatomical and functional reasons. The dorsalis pedis artery may be even safer for preventing emboli from entering brain circulation. Continuous infusion of heparinized solution is mandatory to prevent early clogging or emboli formation. The infusion circuit, for safety reasons, should not contain any air. Monitoring of the infusion flow rate should be encouraged since continuous infusion via flush devices either with infusion pumps or pressure bags has potential problems. ${ }^{3}$

\section{Intra-arterial electrodes}

Full use of the arterial line in children can be attained by inserting $\mathrm{PO}_{2}$ and/or $\mathrm{PCO}_{2}$ electrodes inside the catheter and monitoring blood gas data continuously. Many trials have been reported. Our intra-arterial $\mathrm{PO}_{2}$ electrode ( 100 $\mu \mathrm{m})$ can be inserted in the $22 \mathrm{G}$ catheter without sacrificing the pressure wave form or sampling capability. ${ }^{4}$ Insertion, removal and calibration can be performed any time as long as the line is in place and functioning. Continuous heparin infusion is possible and makes clot formation of the electrode surface very unlikely. The basic performance of this electrode is encouraging. Signal gain drift due to protein deposits on the sensor membrane and erratic values produced when the electrode surface touches the blood vessel wall are obstacles which seem to be difficult to overcome with current technology.

\section{Percutaneous monitoring}

transcutaneous $\mathrm{PO}_{2}$ AND $\mathrm{PCO}_{2}$ Electrodes

Transcutaneous $\mathrm{PO}_{2}$ or $\mathrm{PCO}_{2}$ electrodes are frequently used in neonatal medicine but not as much in paediatric anaesthesia or critical care. Transcutaneous $\mathrm{PO}_{2}$ measurements take several minutes to start and are not adequate in older children. The correlation of the data obtained may be better in neonates as the epidermis is less keratinized and the cutaneous capillary bed more dense. However, as the keratinized layer thickens with age, the diffusion gradient for oxygen becomes greater and the correlation with arterial values decreases. Transcutaneous electrodes are subject to many variables that influence skin perfusion such as hypotension, hypothermia, and pharmacological agents. ${ }^{5}$ Patients in the OR or ICU frequently encounter these variables.

\section{PULSE OXIMETRY}

Pulse oximeters, which measure $\mathrm{SpO}_{2}$ transcutaneously, have gained wide acceptance both in the OR and ICU because of less invasiveness, fast responsive, and most importantly easy operation. Pulse oximeters can not only be used as continuous monitors but also as simple pulmonary function devices. The $\mathrm{SpO}_{2}$ measured in room air preoperatively can guide operative and postoperative management.

Accuracy and reliability at relatively low $\mathrm{SpO}_{2}$ ranges are extremely important in the paediatric population where patients with cyanotic heart disease are common. We investigated the reliability of the Ohmeda 3700 pulse oximeter with Flex II probes in the low saturation range in patients with congenital heart disease. Values were compared with the Corning $7400 \mathrm{CO}$-oximeter. The Ohmeda 3700 performed satisfactorily in a clinical setting in the low saturation range ${ }^{6}$ However, comparison of one unit with another is still not possible because of the lack of a standard calibration method.

\section{NEAR INFRARED SPECTROSCOPY (NIRS)}

NIRS is not purely a technique to measure respiratory gas exchange. Its future potential makes it worthy of mention in conjunction with pulse oximeters. NIRS utilizes wave, lengths of almost the same range as pulse oximeters. However, NIRS utilizes laser emission multiple wave lengths and has extremely sensitive photon counting technology. It is possible to measure with current clinical devices the concentrations of $\mathrm{Hb}, \mathrm{HbO}_{2}, \mathrm{Hb}+\mathrm{O}_{2} \mathrm{Hb}$, and $\mathrm{CtO}_{2}-\mathrm{Ct}$ from a distance of $10 \mathrm{~cm}$, or through the cranium of premature babies. It can be used for continuous and non-invasive monitoring of cerebral oxygenation and cerebral blood volume changes. ${ }^{7}$ Usually, two probes are placed on the patient's forehead. Although absolute calibration is not possible with this reflection method, it can be used as a trend monitor of cerebral perfusion.

The NIRS principle can be applied to other organs and it has the potential of becoming a routine tool in anaesthesia and critical care. ${ }^{8}$

\section{Capnometers}

The capnometer, because of its lack of user friendliness, has not attracted the attention of clinicians until recently, although it was introduced decades before the pulse oximeter. Recent advances in electronic technology have resulted in a series of clinically useful capnometers based on a variety of principles including infrared absorption, mass spectrometry, Raman scattering, and photo-acoustic spectroscopy. Some capnometers are capable of measuring anaesthetic and other gas concentrations. ${ }^{9}$

This technique is not only a powerful clinical tool for assuring adequacy of ventilation but also useful to evaluate pulmonary blood flow when ventilation is determined. End-tidal $\mathrm{PCO}_{2}$ measurement can provide breath-to-breath information on alveolar ventilation when there is no severe ventilation/perfusion derangement and wave form confirmation is essential for verification. The 
gradient of arterial and end-tidal $\mathrm{PCO}_{2}$ is normally 2 to 5 $\mathrm{mmHg}$ when measured properly; however, the gradient may become larger when there is an increase in physiological dead space due to overdistension of the lung or diminished pulmonary blood flow from shock, pulmonary embolism or too tight pulmorary artery banding.

\section{$\mathrm{CO}_{2}$ response curve}

Bedside application of the ventilation response to $\mathrm{CO}_{2}$ challenge is an area which will become extremely important in clinical respiratory care. Read's rebreathing method, which is currently considered a research tool, has a good potential of becoming a useful clinical tool. ${ }^{10,11}$

\section{Measurement of lung mechanics}

Lung mechanics measurements have seldom been performed at the bedside in paediatric anaesthesia and critical care due to technical difficulties which come from small and rapid respiration, lack of patient cooperation, use of an uncuffed tracheal tube and relatively higher airway humidity to keep the small airway patent. Many of these obstacles have been overcome recently by computers and commonly available equipment.

\section{Indirect volume measurement}

It is not routine practice in paediatric medicine to measure breath by breath respiration volume continuously, even though several methods are available. A variety of indirect measurement techniques to estimate respiratory volume from thoracic volume changes has been introduced. Some of these include impedance pneumogram, jacket plethysmography, magnetometers and inductance plethysmography. ${ }^{12,13}$

The impedance technique is widely used as a respiratory rate monitor in combination with ECG monitoring because of its simplicity but the specificity of this method is not satisfactory. The inductance method provides quantitative and partitioned information on movements of the rib cage and abdomen noninvasively. This method is still not as simple as we would like, but can provide limited but useful information on FRC changes and flow-volume relationships. This makes it particularly promising for use in paediatric patients.

\section{Flow, volume, and pressure measurement}

A series of pulmonary function measurements can be breath by breath, relatively easily, during mechanical ventilation using a pneumotachometer and a pressure transducer and some adult ventilators incorporate this capability. Continuous display of various curves such as the airway pressure curve, tidal-volume curve, pressurevolume curve during inspiration and flow-volume curve of expiration can be useful. However, because of the difficulty of maintaining airtight airways constantly in the paediatric population, these measurements are usually performed on an intermittent basis.

\section{Airway pressure}

This is probably the simplest and easiest information of lung mechanics to obtain. Peak pressure changes reflect changes in the respiratory system where a predetermined tidal volume is delivered at a predetermined flow rate. Clinically the "effective" dynamic compliance is calculated by dividing the delivered tidal volume by the peak airway pressure minus PEEP. ${ }^{14}$ However, this is not the true dynamic compliance of the total respiratory system, since the peak inspiratory pressure includes both flowresistive and elastic properties of the respiratory system. True dynamic compliance can be calculated by obtaining end-inspiratory pause pressure with end-inspiratory occlusion. The set peak inspiratory pressure to achieve optimal ventilation is used clinically as an index of the dynamic compliance of the respiratory system in paediatric respiratory care where pressure control ventilation (flow-time cycle + pressure plateau) is common.

\section{Pleural pressure}

The oesophageal balloon has been used in physiological research to estimate mean pleural pressure. However, routine clinical application is not feasible because of its cumbersomeness and proven unreliability in infants. ${ }^{15}$ Instead, multiple occlusion and the passive expiratory flow volume are used to evaluate passive respiratory mechanics. The interrupter technique and the forced oscillation technique during mechanical ventilation are also being investigated. ${ }^{16}$

\section{Passive respiratory mechanics}

Passive measurements of respiratory mechanics may be convenient in paediatric anaesthesia and critical care because complete relaxation of the patient is readily obtainable and because the high chest wall compliance of infants makes the total respiratory compliance measurement almost equivalent to the static lung compliance. Also, passive measurements have the advantage of being unaffected by respiratory muscle activity.

Both the passive expiratory flow volume (PEV) and the multiple occlusion (MO) techniques are used successfully in paediatric patients. ${ }^{17}$ It is necessary with both methods to occlude the airway and obtain a relaxed measurement of airway pressure to measure the static compliance of the respiratory system. In the MO method, the airway is briefly occluded numerous times at a range of volumes and the volumes above end-expiratory level are divided by the corresponding airway occlusion pressures. Compliance is calculated by least square regression analysis of 
lume/pressure data. ${ }^{18}$ In the PEV method, the total atory compliance can be derived from a passive ttory curve obtained after a single occlusion at endation. Compliance can be calculated by dividing the iolated zero flow volume by airway occlusion Ire. The resistance of the total respiratory system ie time constant can also be obtained. The tracheal is a major component of measured resistance in Ited patients. The PEV method is useful clinically se of its safety and ease of performance even though ll measurements are usually taken. ${ }^{19}$

num expiratory flow volume curves (MEFV)

MEFV obtained during a forced vital capacity euvre is a well-established pulmonary function test luate both large and small airway function. ${ }^{20}$ The :ation of this test was limited to older children who lore cooperative and capable of performing fully ional forced expiration. Two techniques which can plied during anaesthesia and critical care have been sped to produce MEFV in children who are not le of performing voluntary forced expiration.

ITION FLOW VOLUME TECHNIQUE ${ }^{2 I}$

rate negative pressure $\left(-40 \mathrm{cmH}_{2} \mathrm{O}\right)$ with a large apability is applied to the tracheal tube at maximal on of the lung with this technique. MEFV is led while the lungs are rapidly deflated. The $\dot{V}_{\max }$ ound with this method although the peak inspiratory ate cannot be compared directly with the convenmethod. The technique is safe, reproducible and an nely sensitive test to measure small airway function. it was found to be a useful test for large airway on in selected patients.

\section{AL EXPIRATORY FLOW VOLUME CURVE (SQUEEZE NIQUE) $)^{22}$}

s a technique to obtain a partial expiratory flow le curve by rapidly applying pressure around the ; of infants with an inflatable jacket at endation. The $\dot{V} \max$ at FRC is measured. It can be $d$ to non-intubated infants although full MEFV is tainable.

$\rho$ vital capacity and peak inspiratory flow rate tive assessment of the ability to maintain adequate neous ventilation in patients following long-term nical ventilation or anaesthesia, or who have been sedatives or muscle relaxants is a daily concern. We ely measure crying vita dcapacity (CVC) and maxinspiratory pressure (MIP) at FRC prior to extuba$\mathbf{n}$ addition to careful clinical evaluation of airway is and confirmation of stable respiratory status on
CPAP. A crying vital capacity of at least twice the normal tidal volume, or over $15 \mathrm{ml} \cdot \mathrm{kg}^{-1}$ appears to be a useful index except in cases with upper airway problems obscured by tracheal tubes. A minimum MIP of 35 $\mathrm{cmH}_{2} \mathrm{O}$ is a useful index but less specific than CVC. Recently, we found that a peak inspiratory flow rate (PIFR) of over $3.5 \mathrm{ml} \cdot \mathrm{sec}^{-1} \cdot \mathrm{cm}^{-1}$ measured during the CVC manoeuvre to be an excellent addition to extubation criteria, especially eliminating unsuccessful extubation due to unnoticed tracheobronchmalacia. ${ }^{23}$

\section{Summary}

Respiratory monitoring of children during general anaesthesia and critical care is in its early stages. Acquisition of physical information remains of great importance because of the difficulties in obtaining specific and objective data from paediatric patients. Many of the obstacles presented by them, such as small and rapid respiration, lack of patient cooperation, use of an uncuffed tracheal tube and relatively higher airway humidity to keep the small airway patent, have been overcome recently by sophisticated technology based on well known principles and thoughtful use of computers. It is now possible to monitor and apply many pulmonary function tests at the bedside that were once confined to the laboratory.

\section{References}

1 Boysen PG, Broome JA. Noninvasive monitoring of lung function during mechanical ventilation. Crit Care Clin 1988; 4: 527-44.

2 Miyasaka K, Edmonds JF, Conn AW. Complications of radial artery lines in the pediatric patients. Can Anaesth Soc J 1976; 23: 9-13.

3 Hart GK, Gibbs NM, Cameron PD et al. Pressure infusors: variability in delivered infusion pressure. Crit Care Med 1984; 12: 893-5.

4 Katayama $M$, Miyasaka $K$. Intra-arterial continuous $\mathrm{PO}_{2}$ monitoring by an ultrafine microelectrode (abstract). Crit Care Med 1987; 15: 357.

5 Barker SJ, Tremper KK. Transcutaneous oxygen tension: a physiological variable for monitoring oxygenation. J Clin Monit 1985; 1: 130-3.

6 Miyasaka K, Katayama M, Kusakawa I et al. Usc of pulsc oximetry in neonatal anesthesia. J Perinatol 1987; 7 . 343-5.

7 Jobsis $F F$. Noninvasive infrared monitoring of cerebral and myocardial sufficiency and circulatory parameters. Science 1977; 198: 1264-7.

8 Wyatt J. Noninvasive brain monitoring with near infrared spectroscopy. Crit Care Digest 1989; 8: 47-8.

9 Gravenstein IS, Paulus DA, Hayes TJ. Capnography in Clinical Practice. Boston: Butterworths, 1988. 
10 Read DJC. A clinical method for assessing the ventilatory response to carbon dioxide. Australian Annuals of Medicine 1967; 16: 20-32.

11 Honma $Y$, Wilkes D, Bryan MH, Bryan AC. Rib cage and abdominal contributions to ventilatory response to $\mathrm{CO}_{2}$ in infants. J Appl Physiol 1984; 56: 1211-16.

12 Kattan $M$, Miyasaka $K$, Volgyesi $G$, Froese AB. A respiratory jacket for ventilatory measurements in children. J Appl Physiol 1978; 45: 630-6.

13 Sackner MA. Monitoring of ventilation without physical connection to the airway: a review. ISAM Proceedings of the Third International Symposium on Ambulatory Monitoring. London: Academic Press, 1980.

14 Milic-Emili J, Gottfried SB, Rossi A. Non-invasive measurement of respiratory mechanics in ICU patients. Int J Clin Monit Comput 1987; 4: 11-20.

15 Lesouef PN, Lopes JM, England SJ et al. Influence of chest wall distortion on esophageal pressure. J Appl Physiol 1983; 55: 353-5.

16 Sly PD, Brown KA, Bates BHT et al. Noninvasive determination of respiratory mechanics during mechanical ventilation of neonates: a review of current and future techniques. Pediatr Pulmonol 1988; 4: 39-47.

17 Guslits BG, Wilkie RA, England SJ et al. Comparison of methods of measurement of compliance of the respiratory system in children. Am Rev Respir Dis 1987; 136: 727-29.

18 Fletcher $M E$, Stocks $J$, Ridley $S$ et al. Total respiratory compliance during anesthesia in infants and young children. Br J Anaesth 1989; 63: 266-75.

19 Lesouef PN, England SJ, Bryan AC. Passive respiratory mechanics in newborns and children. Am Rev Respir Dis 1984; 129: 552-56.

20 Dayman $H$. Mechanics of airflow in health and in emphysima. J Clin Invest 1951; 30: 175-9.

21 Motoyama EK. Pulmonary mechanics during early postnatal years. Am Rev Respir Dis 1977; 11: 220-3.

22 Morgan WJ, Geller DE, Tepper RS et al. Partial expiratory flow volume curves in infants and young children. Pediatr Pulmonol 1988; 5: 232-43.

23 Osada A, Katayama M, Sugiura $M$, Miyasaka $K$. A new extubation criteria. Jap Pediatr 1989; 30: 621-8. 


\section{La surveillance respi- ratoire de l'enfant en salle d'opération et en unité de réanimation}

Les enfants pendant l'anesthésie générale et la réanimation vont souvent avoir besoin de support respiratoire intensif. Cependant, l'évaluation respiratoire de routine n'ira pas souvent plus loin que l'analyse des gaz sanguins, probablement parce que l'on croit que des épreuves de fonction respiratoire sont très difficiles à obtenir chez les patients pédiatriques.

La petite taille des patients pédiatriques rend la discrimination des signaux difficile pour toutes les variables respiratoires mesurées (comparativement au bruit de fond). Des signaux continus, une réponse rapide et des moyens moins invasifs sont des caractéristiques importantes du monitoring pédiatrique et vont souvent contrebalancer l'importance de la précision et de spécificité. Le manque de précision et de spécificité peuvent être assez bien compensées par l'usage combiné de plusieurs variables indirectes mais à enregistrement continu. On rencontre souvent des situations en clinique pédiatrique où l'on doit se contenter d'une information de moins bonne qualité plutôt que de ne pas en avoir du tout. Des progrès récents dans la physiologie respiratoire et la technologie informatique ont permis de rendre utiles même au chevet, plusieurs épreuves de fonction respiratoire avancées qui auparavant étaient réservées au laboratoire.

\section{Observation des mouvements de la cage thoracique}

A cause des difficultés d'obtention des données spécifiques et objectives venant des patients pédiatriques, l'acquisition de données d'observation et d'examen demeure d'importance primordiale. En plus de tous les signes habituels de la défaillance respiratoire, telles que l'augmentation de fréquence respiratoire, la rétraction sternale et l'utilisation des muscles accessoires de la respiration, une évaluation soigneuse de la coordination de la cage thoracique et de l'abdomen est importante. Pendant l'inspiration spontanée la paroi thoracique et l'abdomen devraient avoir une excursion excentrique synchrone. On va noter une respiration paradoxale ou une respiration non coordonnée, ce qui veut dire que l'abdomen et la cage thoracique bougent en direction opposée, lorsqu'un patient souffrira de paralysie du nerf phrénique ou de fatigue des muscles respiratoires.'

\section{Le stéthoscope précordial}

L'importance de la surveillance continue avec un stéthoscope précordial se passe de commentaires, surtout lors de l'anesthésie. Un stéthoscope est probablement le moniteur unique le plus utile en anesthésie. Il peut évaluer la fonction cardiaque et respiratoire en même temps, de façon continue et non-invasive. C'est un appareil très économique, qui ne demande pas d'électricité et qui maintient l'anesthésiste tout près de son patient en tout temps. Nous avons fait une enquête récemment dans 14 hôpitaux pédiatriques au Japon qui montre que l'utilisation continue du stéthoscope précordial dans tous les cas, en plus de la mesure de la température et de la pression artérielle, est devenu obligatoire.

\section{Mini-fibrobronchoscope}

La majorité des patients en anesthésie pédiatrique et en réanimation ont des tubes endotrachéaux ou des canules de trachéostomie, de telle sorte que le maintien de la perméabilité des voies aériennes est d'extrême importance. Un fibrobronchoscope de petit calibre est un outil utile pour évaluer la perméabilité des voies aériennes au chevet. Le plus petit fibroscope avec angulation ajustable, a un diamêtre extérieur de $2,4 \mathrm{~mm}$ et passe à travers un tube de diamètre de $2,5 \mathrm{~mm}$ assez facilement. La confirmation de la perméabilité du tube trachéal et le diagnostic différentiel de l'obstruction des voies aériennes se fera très facilement et rapidement en évitant des réintubations inutiles.

\section{Variables d'échange gazeux}

Ligne artérielle et analyses de sang artériel

Même si des moyens de surveillance moins invasifs sont préférables, et même si des progrès importants sont survenus, telle que la mesure non-invasive de la pression artérielle, l'oxymétrie digitale et la capnométrie, l'utilisation de la ligne artérielle ne peut être encore éliminée des unités de réanimation pédiatrique. Notre expérience dans l'utilisation des lignes artérielles chez les patients pédiatriques dans les deux dernières décades nous a enseigné d'importantes leçons. Il est important de choisir une artère 
périphérique plutôt qu'une artère centrale, et de faire l'insertion par voie transcutanée plutôt que par approche chirurgicale. ${ }^{2}$ Les cathéters non biseautés et de petit calibre (22 ou $24 \mathrm{~g}$ ) devraient être utilisés. Le côté gauche est préférable pour des raisons anatomiques et fonctionnelles lorsque l'on choisit l'artère radiale. L'artère pédieuse peut être encore plus sécuritaire lorsque l'on veut prévenir des embolies cérébrales. Il faut absolument utiliser une infusion continue de solution héparinée pour prévenir la thrombose ou la formation d'embolie. Le circuit d'infusion ne devrait pas contenir d'air pour des raisons de sécurité. Il faut surveiller constamment le débit de l'infusion puisqu'une infusion continue par système de valve, que ce soit avec des pompes à infusion ou des sacs à pression, présente des problèmes potentiels. ${ }^{3}$

\section{Électrodes intra-artérielles}

Un utilisation plus complète de la ligne artérielle chez l'enfant peut se faire par l'insertion d'électrodes de $\mathrm{PO}_{2}$ et de $\mathrm{PCO}_{2}$ à l'intérieur du cathéter, ce qui permet de monitorer continuellement les gaz sanguins. Plusieurs travaux ont paru sur le sujet. Notre électrode de $\mathrm{PO}_{2}(100$ $\mu \mathrm{m}$ ) peut être insérée dans une canule $22 \mathrm{~g}$ sans diminuer la qualité de la courbe de pression ou la capacité d'échantillonnage ${ }^{4} \mathrm{~L}$ 'insertion, le retrait et la calibration peuvent être accomplis en tout temps, tant et aussi longtemps que la ligne est en place et est fonctionnelle. Une infusion continue d'héparine est possible et rend la formation de caillots à la surface des électrodes peu probable. La performance actuelle de cette électrode est actuellement encourageante. La variabilité des signaux à cause de la déposition de protéines sur la membrane du détecteur et des valeurs erronnées produites quand la surface de l'électrode touche la paroi du vaisseau sont des obstacles qui semblent être difficiles à surmonter avec la technologie actuelle.

\section{Monitoring percutané}

\section{ÉLECTRODES À $\mathrm{PO}_{2}$ À PCO $\mathrm{PCO}_{2}$ TRANSCUTANÉES}

Des électrodes transcutanées à $\mathrm{PO}_{2}$ et $\mathrm{PCO}_{2}$ sont utilisées souvent en médecine néonatale mais moins fréquemment en anesthésie ou réanimation pédiatrique. La mesure de $\mathrm{PO}_{2}$ transcutanée demande un délai de plusieurs minutes avant d'être fonctionnelle et n'est pas adéquate chez les enfants plus vieux. La corrélation des données obtenues peut être meilleure chez les nouveau-nés puisque leur épiderme est moins kératinisé et que le lit capillaire sous-cutané est plus dense. Cependant, à mesure que la couche kératinisé s'épaissit avec l'âge, le gradient de diffusion pour l'oxygène devient plus grand et la corrélation avec les valeurs artérielles diminue. Les électrodes transcutanées sont sujettes à l'effet de plusieurs facteurs qui influencent la perfusion cutanée telles l'hypotension, l'hypothermie, et certains agents pharmacologiques. ${ }^{5}$ Les patients en salle d'opération ou en unité de soins intensifs vont souvent présenter ces conditions défavorables.

\section{OXYMETRIE CUTANÉE}

Les oxymètres cutanés, qui mesurent la saturation de l'oxygène par voie transcutanée, font l'objet d'un accueil très favorable autant dans la salle d'opération que dans les unités de réanimation, parce qu'ils sont moins invasifs, donnent une réponse rapide et surtout sont faciles à utiliser. Les oxymètres cutanés peuvent non seulement être utilisés sur un mode continu mais aussi deviennent des appareils simples de mesure de la fonction pulmonaire. La saturation mesurée à l'air ambiant en préopératoire peut orienter la conduite opératoire et postopératoire. La précision et la reproductibilité à des niveaux de saturation faibles sont extrêmement importantes dans la population pédiatrique, ou les patients avec maladie cardiaque congénitale cyanotiques sont nombreux. Nous avons évalué la fiabilité de l'oxymètre Ohmeda $\mathbf{3 7 0 0}$ avec sonde Flex II dans les bas niveaux de saturation chez des patients avec maladie cardiaque congénitale. Les valeurs ont été comparées avec celles obtenues par le co-oximètre Corning 7400. L'appareil Ohmeda 3700 a donné des résultats satisfaisants dans un environnement clinique, pour les bas niveaux de saturation. ${ }^{6}$ Par contre la comparaison d'une telle unité avec d'autres du même type n'est pas encore possible à cause de l'absence de méthode uniforme de calibration.

\section{SPECTROSCOPIE À PROCHE INFRA-ROUGE (NIRS)}

La spectroscopie à proche infra-rouge n'est pas seulement une technique de mesure des échanges respiratoires. Son potentiel la rend digne de mention au même titre que les oxymètres cutanés. Ce type de spectroscopie utilise des longueurs d'ondes dans le même éventail que les oxymètres. Cependant, la spectroscopie à proche infra-rouge utilise une émission de laser à multiple longueurs d'ondes et comprend une technologie extrêmement sensible de décompte de photons. Il est possible de mesurer les concentrations d'hémoglobine, d'oxy-hémoglobine, de désoxyhémoglobine d'une distance de $10 \mathrm{~cm}$, ou à travers le crâne d'un prématuré, avec l'appareillage disponible actuellement. Ce spectroscope peut être utilisé de façon continuelle et non-invasive pour évaluer l'oxygénation cérébrale et les changements de volume sanguin cérébral. ${ }^{7}$ Habituellement, deux sondes sont placées sur le front du patient. Même si une calibration parfaite n'est pas possible avec cette méthode par réflecxion, on peut l'utiliser comme moniteur de tendances de la perfusion cérébrale.

Le principe de la spectroscopie à infra-rouge peut être 
utilisé pour d'autres organes et a le potentiel pour devenir un outil courant en anesthésie et en soins intensifs. ${ }^{8}$

\section{Les capnomètres}

Le capnomètre, à cause de sa difficulté d'utilisation, n'a pas attiré l'attention des cliniciens jusqu'à récemment, même s'il a été introduit dans la pratique plusieurs décades avant l'oxymètre cutané. Des progrès récents dans la technologie électronique ont produit une série de capnomètres utiles en clinique dont le fonctionnement est basé sur une variété de principes incluant l'absorption infra-rouge, la spectométrie de masse, la dispersion Raman, et la spectroscopie photo-acoustique. Quelques capnomètres sont capables de mesurer la concentration des agents anesthésiques et autres ga $\iota .{ }^{9}$

Cette technique n'est pas seulement un puissant outil en clinique pour obtenir une bonne ventilation mais elle est aussi très utile pour évaluer le débit sanguin pulmonaire lorsque l'on connait la ventilation. La mesure du $\mathrm{CO}_{2}$ en fin d'expiration peut amener une information continue sur la ventilation alvéolaire lorsqu'il n'y a pas de distorsion sévère du rapport ventilation/perfusion; une confirmation de la forme de la courbe est essentielle pour en assurer la vérification. Le gradient entre la $\mathrm{PCO}_{2}$ artériel et la $\mathrm{PCO}_{2}$ de fin d'expiration est normalement de 2 à $5 \mathrm{mmHg}$ lorsque mesuré adéquatement. Cependant ce gradient peut devenir plus important lorsqu'il y a une augmentation de l'espace mort physiologique, soit à cause d'une surdistention du poumon ou une réduction du flot sanguin pulmonaire à la suite de choc, d'embolie pulmonaire ou de resserrement trop important de l'artère pulmonaire (banding).

\section{Courbe de réponse au $\mathrm{CO}_{2}$}

L'utilisation au chevet des méthodes d'analyse de réponses à une stimulation au $\mathrm{CO}_{2}$ est un secteur qui va devenir extrêmement important en soins cliniques de la respiration. La méthode de réinspiration de Read, qui est actuellement considérée comme un outil de recherche, a un bon potentiel pour devenir un instrument utile en clinique. ${ }^{10,11}$

\section{Mesure de la mécanique pulmonaire}

Les mesures de mécanique pulmonaire sont rarement faites au chevet des patients pédiatrique, en anesthésie ou aux soins intensifs, à cause de difficultés techniques originant d'une respiration rapide et de petit volume, une absence de coopération du patient, l'utilisation de tubes endotrachéaux sans ballonnet, et une humidité des voies aériennes relativement plus importante, utilisée pour maintenir ces petites voies aériennes perméables. Plusieurs des obstacles ont récemment été surmontés par des ordinateurs et un équipement disponible couramment.

\section{Mesure indirecte du volume}

On ne mesure pas de routine en pédiatrie le volume respiratoire respiration par respiration de façon continue, même si plusieurs méthodes sont disponibles. Un bon nombre de techniques de mesure indirecte du volume respiratoire ont été proposés. Quelques unes de celles-ci comprennent la pneumographie par impédance, la pléthysmographie par impédance, les magnétomètres et la plethysmographie par inductance. ${ }^{12,13}$

Les techniques par impédance sont couramment utilisées pour l'analyse de fréquence respiratoire en combinaison avec l'électrocardiographie, à cause de leur simplicité ; cependant la spécificité de ces méthodes n'est pas satisfaisante. La méthode par inductance donne une information quantitative et fragmentée sur les mouvements de la cage thoracique et de l'abdomen, de façon non-invasive. Cette méthode n'est pas encore aussi simple que l'on voudrait, mais peut donner une information limitée mais utile sur les changements de capacité résiduelle fonctionnelle et les inter-relations flot/volume. Ceci rend la méthode par inductance prometteuse chez les patients pédiatriques.

\section{Mesures de débit, de volume et de pression}

Un bon nombre de mesures de fonction pulmonaire peuvent être faites respiration par respiration, relativement facilement, en utilisant un pneumotachomètre et un capteur de pression pendant la ventilation mécanique. Quelques ventilateurs pour adultes incorporent cette possibilité. L'illustration continue des diverses courbes telles que la courbe de pression des voies aériennes, la courbe de volume courant, la courbe pression-volume pendant l'inspiration et l'expiration peut être utile. Cependant, à cause de la difficulté d'obtenir une étanchéité des voies aériennes de façon constante dans la population pédiatrique, ces mesures sont habituellement faites sur une base intermittente.

\section{La pression des voies aériennes}

Ceci est probablement l'information la plus simple et la plus facile à obtenir sur la mécanique pulmonaire. Les changements dans les pics de pression reflètent des changements dans le système respiratoire où un volume courant prédéterminé est administré à un débit prédéterminé. Sur une base clinique la compliance dynamique «effective» est calculée en divisant le volume courant donné par la valeur maximale de pression, moins le PEEP. ${ }^{14}$ Cependant, ceci ne constitue pas la véritable compliance dynamique du système respiratoire total, puisque la pression inspiratoire maximale comprend autant les propriétés élastiques que de résistance au flot du système respiratoire. La compliance dynamique vraie peut être calculée en obtenant la pression au moment de la 
pause de fin d'inspiration avec une occlusion en fin d'inspiration. La valeur des pressions maximales d'inspiration déterminée pour obtenir une ventilation optimale est utilisée cliniquement comme indice de la compliance dynamique du système respiratoire dans les unités de soins pédiatriques où la ventilation par relaxation de pression est courante (cyclage temps-débit + plateau de pression).

\section{Pression pleurale}

Le ballon œsophagien a été utilisé en recherche physiologique pour estimer la pression pleurale moyenne. Cependant, son utilisation courante en clinique est inaccesible à cause de son encombrement et de son manque de fiabilité démontré chez les enfants. ${ }^{15} \mathrm{~A}$ la place de cette méthode, l'occlusion multiple et la courbe débit-volume (d'expiration passive) sont utilisées pour évaluer la mécanique respiratoire passive. La technique par interrupteur et celle avec oscillation forcée pendant la ventilation mécanique sont aussi en évaluation. ${ }^{16}$

\section{Mécanique respiratoire passive}

Les mesures passives de la mécanique respiratoire peuvent être utiles en anesthésie et réanimation pédiatrique à cause de la relaxation complète disponible chez le patient et parce que la compliance de la cage thoracique très élevée chez les enfants rend la mesure de la compliance respiratoire totale à peu près équivalente à celle de la compliance statique. De plus, les mesures passives ont l'avantage de ne pas être influencées par l'activité des muscles respiratoires.

Les techniques de mesure du volume du flot expiratoire et d'occlusion multiple sont utilisées avec succès chez des patients pédiatriques. ${ }^{17}$ Avec les deux méthodes, il est nécessaire de provoquer une occlusion des voies aériennes et d'obtenir une mesure de leur pression dans un état de relaxation, pour mesurer la compliance statique du système respiratoire.

Avec la méthode à occlusion multiple, les voies aériennes sont en occlusion brève à de multiples valeurs de volume, et les volumes au-delà du niveau de fin d'expiration sont divisés par les valeurs correspondantes de pression d'occlusion. La compliance est calculée par analyse de régression des données pression/volume (méthode des moindres carrés). ${ }^{18}$

En ce qui concerne la méthode de mesure du volume expiratoire passif, la compliance respiratoire totale peut être déterminée à partir d'une courbe expiratoire passive obtenue après une seule occlusion à la fin de l'inspiration. La compliance peut être calculée en divisant le volume (extrapolé à un flot nul), par la pression des voies aériennes. La résistance du système respiratoire total et la constante de temps peuvent être aussi obtenues. Le tube trachéal contribue de façon majeure à la résistance mesurée chez les patients intubés. La méthode de mesure du volume par débit expiré est utile en clinique à cause de sa sécurité et de la facilité de son utilisation, même si l'on doit prendre plusieurs mesures. ${ }^{19}$

\section{Courbe de volume expiratoire maximal}

Le volume expiratoire maximal obtenu pendant une manœuvre de capacité vitale forcée est un épreuve de fonction respiratoire bien établie, qui aide à mesurer la fonction des voies aériennes de grande et petit calibre. ${ }^{20}$ L'application de cette épreuve était limitée aux enfants plus vieux qui sont plus coopérants et capables de générer volontairement une expiration forcée maximale. Deux techniques utiles pour provoquer un volume expiratoire maximal chez les enfants au préalable incapables de le faire, ont été mise sur pied.

\section{TECHNIQUE DE DÉBIT-VOLUME EN DÉFLATION ${ }^{21}$}

Il s'agit dans cette technique de créer une inflation maximale du poumon par le tube trachéal et ensuite d'appliquer une pression négative $\left(-40 \mathrm{cmH}_{2} \mathrm{O}\right)$ avec flot élevé. La courbe débit/volume expiratoire est obtenue pendant que les poumons sont dégonflés rapidement. Le V̀max 25 pourra être retrouvé par cette méthode même si le débit inspiratoire maximal ne peut ètre comparé directement avec celui obtenu par la méthode conventionnelle. La technique est sécuritaire, reproductible et est une méthode extrêmement sensible pour mesurer la fonction des petites voies aériennes. Elle est aussi utile pour mesurer la fonction des grosses voies aériennes chez certains patients choisis.

\section{LA COURBE DEBIT-VOLUME EXPIRATOIRE PARTIELLE (SQUEEZE TECHNIQUE) ${ }^{22}$}

Il s'agit d'une technique qui permet d'obtenir une courbe débit-volume expiratoire partielle en imprimant rapidement, à la fin de l'inspiration, une pression sur le corps des enfants avec une veste gonflable. Le débit maximal au moment de l'atteinte de la capacité résiduelle fonctionnelle est mesuré. Cette méthode peut être utilisée chez tous les enfants non-intubés même si une courbe débitvolume expiratoire maximal n'est pas accessible.

\section{Capacité vitale pendant les pleurs et débit inspiratoire maximal}

La mesure objective de la capacité de maintenir une ventilation spontanée adéquate chez des patients émergeant d'une ventilation mécanique prolongée, ou qui ont reçu des sédatifs et/ou des relaxants musculaires, constitue une préoccupation quotidienne. Nous mesurons de routine, avant l'extubation, la capacité vitale pendant les pleurs, et la pression inspiratoire maximale à l'atteinte de 
la capacité résiduelle fonctionnelle, en plus d'évaluer les réflexes des voies aériennes et de confirmer un état respiratoire stable sur CPAP. Une capacité vitale pendant l'epreuve d'au moins le double du volume courant normal, ou au-delà de $15 \mathrm{ml} \cdot \mathrm{kg}^{-1}$ semble être un indice utile, sauf dans les cas où les voies aériennes supérieures encombrées par des tubes endotrachéaux peuvent amener des problèmes. Une pression inspiratoire minimale de 35 $\mathrm{cmH}_{2} \mathrm{O}$ est aussi un indice important, mais moins spécifique que la capacité vitale pendant les pleurs. Récemment nous avons trouvé qu'un débit inspiratoire maximal d'au delà de $3,5 \mathrm{ml} \cdot \mathrm{sec}^{-1} \cdot \mathrm{cm}^{-1}$ (hauteur) mesuré pendant la manœuvre de capacité vitale, semble être une excellente addition à nos critères d'extubation ; ceci permet de diminuer nos échecs à l'extubation à cause de trachéo-bronchomalacie insoupsonnée. ${ }^{23}$

\section{Résumé}

Le monitoring respiratoire des enfants pendant l'anesthésie générale et la réanimation est encore dans ses stages de développement. L'acquisition de données directes revêt une grande importance à cause des difficultés d'obtenir des données spécifiques et objectives chez les patients pédiatriques. Plusieurs des obstacles occasionnés par ces patients, tels qu'une respiration rapide et de petit volume, une absence de coopération du patient, l'utilisation de tube trachéaux sans ballonnet et une humidité dans les voies aériennes relativement plus élevée pour conserver ces petites voies aériennes perméables, ont récemment été surmontés par une technologie sophistiquée basée sur des principes bien connus et l'usage approprié d'ordinateurs. Il est maintenant possible d'utiliser plusieurs épreuves fonctionnelles respiratoires au chevet des patients, alors qu'auparavant elles étaient confinées au laboratoire.

\section{Références}

(Voir page Scxxvii) 